\title{
Alveolar gas concentrations of fluorocarbons-11 and -12 in man after use of pressurized aerosols
}

\author{
G. H. DRAFFAN, C. T. DOLLERY, FAITH M. WILLIAMS, \\ and R. A. CLARE \\ MRC Clinical Pharmacology Research Group, Royal Postgraduate Medical School, \\ Du Cane Road, London W12
}

\begin{abstract}
Draffan, G. H., Dollery, C. T., Williams, Faith M., and Clare, R. A. (1974). Thorax, 29, 95-98. Alveolar gas concentrations of fluorocarbons-11 and -12 in man after use of pressurized aerosols. In dogs, inhalation of fluorocarbon aerosol propellants sensitizes the heart to arrhythmias provoked by intravenous injection of adrenaline. In this research, the concentrations of fluorocarbons-11 and $-12, \mathrm{CCl}_{3} \mathrm{~F}$ and $\mathrm{CCl}_{2} \mathrm{~F}_{2}$, have been measured in alveolar gas in man after using pressurized aerosol inhalers. Fluorocarbons were measured breath by breath using an AEI MS12 mass-spectrometer modified to allow sampling from a respiratory mouthpiece.

After a single inhalation from an inhaler by six normal volunteers the mean concentration of fluorocarbon-12 in alveolar gas had reached $5.5 \mu \mathrm{g} / \mathrm{ml}$, giving a mean apparent volume of distribution of 7.94 litres compared with the mean predicted total lung capacity of 6.61 litres. These results suggest that most of the fluorocarbon expelled from the inhaler entered the alveolar gas. The mean alveolar concentration of F-11 was $2.7 \mu \mathrm{g} / \mathrm{ml}$ and the mean apparent volume of distribution was 12.46 litres. The higher volume of distribution with the less volatile F-11 probably reflects the amount dissolved in lung tissue and pulmonary capillary blood. Similar results were obtained in two patients with obstructive airways disease.

One volunteer took an inhalation on every breath up to two minutes and reached an alveolar concentration of F-11 of $29.6 \mu \mathrm{g} / \mathrm{ml}$ and of F-12 of $66.9 \mu \mathrm{g} / \mathrm{ml}$. The concentration of F-11 required to sensitize the dog heart to arrhythmias was $68 \mu \mathrm{g} / \mathrm{ml}$. Thus there should be no hazards from the amount entering alveolar gas in normal use after a single inhalation. Inhalation upon every breath over a period raises the alveolar concentration to one approaching that which, in the dog, might be hazardous.
\end{abstract}

The increase in deaths from asthma in Britain between 1960 and 1967, although never fully explained, is generally accepted to have been linked with the use of pressurized aerosols for administration of bronchodilator drugs (Speizer, Doll, and Heaf, 1968 ; Speizer, Doll, Heaf, and Strang, 1968). Most of these aerosols contain fluorocarbons-11 and $-12\left(\mathrm{~F}-11, \mathrm{CCl}_{3} \mathrm{~F} ; \mathrm{F}-12, \mathrm{CCl}_{2} \mathrm{~F}_{2}\right)$ as propellants. Interest in a possible role for these compounds in causing sudden death was aroused by reports of deaths among 'solvent sniffers' in the United States of America (Bass, 1970) and the demonstration in conscious dogs that inhalation of $1.25 \% \quad(68$ $\mu \mathrm{g} / \mathrm{ml}) \mathrm{F}-11$ or $8 \%(380 \mu \mathrm{g} / \mathrm{ml}) \mathrm{F}-12$ for five minutes would sensitize them to serious ventricular

Requests for reprints to: Dr. C. T. Dollery, Royal Postgraduate Medical School, Du Cane Road, London W12 arrhythmias provoked by intravenous injection of adrenaline (Clark and Tinston, 1972a, b).

The present investigation was undertaken to measure alveolar gas concentrations of these substances after use of an inhaler and to compare the concentrations with those known to sensitize the animal hearts to arrhythmias. As wide individual differences in concentration were found, including some individuals who had almost no fluorocarbon in their alveolar gas, the study was extended to include a breath-actuated inhaler ('Autohaler'; D'Arcy and Kirk, 1971) which avoids the difficulty of mistiming the valve actuation.

Mass spectrometry was used in the measurement of F-11 and F-12 on successive breaths up to two minutes after inhalation from the aerosols. 
The mass spectra differed significantly only in the higher mass fragments (F-12, m/e 85; F-11, m/e 101). A simple two-stage continuous inlet system for breath analysis (Muysers and Smidt, 1972) was fitted to an AEI MS 12 mass spectrometer.

\section{METHODS}

MASS SPECTROMETRY An AEI MS 12 mass spectrometer operated at a resolving power of 800 , basic accelerating voltage of $8 \mathrm{kV}$, and ionizing voltage of $70 \mathrm{eV}$ was used. The inlet system for breath analysis consisted of a $3 \mathrm{ft} 0.013$ in i.d. stainless steel capillary heated to $70^{\circ}$ connecting a mouthpiece to a bypasspumped well of volume $0.49 \mathrm{ml}$. The exit of the capillary was approximately 0.01 in from a porous plug leak. The path to the ion chamber on the high vacuum side was 4.5 in $\times \frac{1}{8}$ in i.d. in glass. The bypass line was $6 \mathrm{ft} \times \frac{1}{4}$ in i.d. to a two-stage rotary pump. The flow rate in the capillary was $55 \mathrm{ml} / \mathrm{min}$.

F-12 was monitored at $\mathrm{m} / \mathrm{e} 85$ (M-Cl) at $8 \mathrm{kV}$ and F-11 at $\mathrm{m} / \mathrm{e} 101$ (M-Cl) focussed at a lower accelerating voltage. Voltages were selected using an accelerating voltage alternator (AVA) in manual mode, F-11 and F-12 being monitored on alternate breaths. Values for F-11 were corrected for a contribution at $\mathrm{m} / \mathrm{e} 101$ due to $\mathrm{F}-12$ (6\% of $\mathrm{m} / \mathrm{e} 85)$. Lag time to first observed response to sample was $0 \cdot 12$ seconds and transition time to $95 \%$ response, 0.96 seconds, for both fluorocarbons.

Mixtures of F-11 and F-12 of approximate concentrations in the range $1-60 \mu \mathrm{g} / \mathrm{ml}$ in air saturated with water vapour at room temperature were prepared in heat-sealable polyester bags. Samples (1.0 $\mathrm{ml}$ ) were removed in gas-tight syringes through silicone rubber plugs and the F-11 and F-12 concentrations were measured by gas chromatography (flame ionization detection) using a $6 \mathrm{ft} \times \frac{1}{4}$ in o.d. column of $15 \%$ dihexylethyl sebacate at $80^{\circ}$ in a Pye 104 chromatograph. Mass spectrometer response to F-11 and F-12 was determined with these standards. Sampling times were limited to less than five seconds attachment to the inlet capillary ; no relative enrichment of either component or significant loss by dissolution in the material of the bag was observed during a day's calibration. The precision of measurement of F-11 was $\pm 12 \%$ (SD) at $2 \mu \mathrm{g} / \mathrm{ml}$ and of $\mathrm{F}-12 \pm 10 \%$ (SD) at $4 \mu \mathrm{g} / \mathrm{ml}$ ).

MEASUREMENT OF LUNG CONCENTRATIONS The aerosol inhaler used was Th $1165 \mathrm{a}$ placebo (Boehringer) releasing $50 \mu \mathrm{l}$ of liquified fluorocarbons of composition $28.7 \mathrm{mg} \mathrm{F}-11$ and $41.0 \mathrm{mg}$ F-12 per actuation. Six healthy adult volunteers and two patients with obstructive airway disease were asked to make a maximal inspiration from the resting expiratory level while actuating this inhaler, to hold their breath for five seconds, and then to breath at a normal rate through the mouthpiece. F-11 and F-12 were recorded on alternate expired breaths for 30 to 120 seconds.
In three further studies, a volunteer inhaled one puff from the Th 1165a placebo on successive breaths for 30,60 , and 120 seconds $(6,12$, and 24 puffs respectively). In these acute studies the electrocardiogram was recorded from precordial electrodes and charted on a pen recorder (Devices M4).

In an additional group of seven volunteers, a breathactuated inhaler was used (Autohaler 710403 placebo (Riker) ; $25 \mu$ l per valve actuation of composition $1: 2: 1$ by weight of $\mathrm{F}-11, \mathrm{~F}-12$, and $\mathrm{F}-114, \mathrm{C}_{2} \mathrm{Cl}_{2} \mathrm{~F}_{4}$ ). Due to the superimposed mass spectrum of $F-114$, accurate quantitation of $\mathrm{F}-11$ and F-12 was not attempted in these studies.

\section{RESULTS}

SINGLE INHALATIONS Two types of concentration profile were seen on the first expiration following use of the inhaler (Fig. 1).

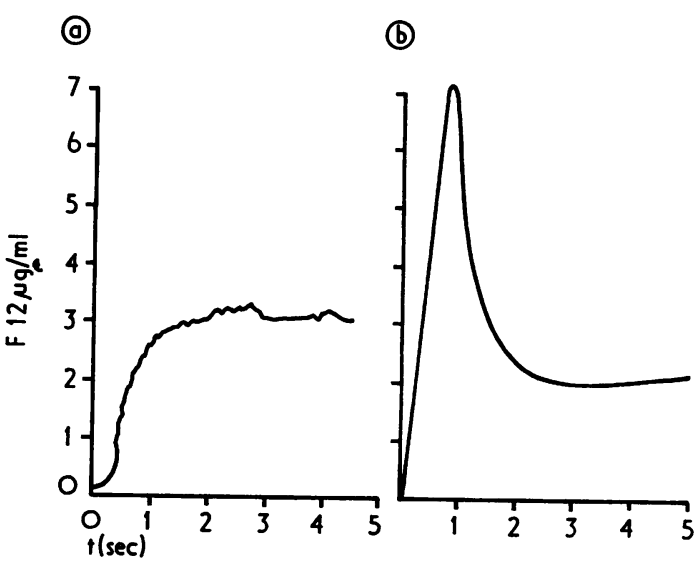

FIG. 1. Fluorocarbon-12 concentration in the first expired breath after inhalation from placebo aerosol (Th 1165a) following actuation of the inhaler (a) at the start of inspiration and (b) late in inspiration.

Time zero represents the start of expiration.

The first was a rapid and progressive rise to a plateau after a short initial lag while the dead space was cleared (Fig. 1a). This is the pattern predicted from inserting a pulse of fluorocarbon into the inhaled gas during the early part of inspiration so that it is flushed into the alveolar gas by air inhaled in late inspiration. Thus the dead-space gas is free of fluorocarbon and there is a delay while it is cleared before the alveolar gas-containing fluorocarbon appears at the sampling tube.

The second pattern consisted of a high spike of fluorocarbon concentration immediately after the start of expiration followed by much lower concentrations later in expiration (Fig. 1b). This 
T A B LE I

ALVEOLAR GAS CONCENTRATIONS OF FLUOROCARBONS-11 AND -12 IN NORMAL SUBJECTS AFTER SINGLE INHALATIONS FROM PLACEBO AEROSOL Th 1165a

\begin{tabular}{|c|c|c|c|c|c|c|c|c|c|}
\hline \multirow{3}{*}{$\begin{array}{c}\text { Subject } \\
1 \\
2 \\
3 \\
4 \\
5 \\
6\end{array}$} & \multirow{3}{*}{$\begin{array}{c}\text { No. of Studies } \\
\\
\\
4 \\
2 \\
3 \\
3 \\
1 \\
1\end{array}$} & \multirow{3}{*}{$\begin{array}{l}\text { Sex } \\
\mathbf{F} \\
\mathbf{M} \\
\mathbf{M} \\
\mathbf{M} \\
\mathbf{M} \\
\mathbf{M}\end{array}$} & \multirow{3}{*}{$\begin{array}{c}\begin{array}{c}\text { Predicted } \\
\text { TLC (1.) }\end{array} \\
\\
\\
4.43 \\
7.05 \\
7.77 \\
6.83 \\
6.75 \\
6.83\end{array}$} & \multicolumn{2}{|c|}{$\begin{array}{c}\text { Peak Alveolar Gas } \\
\text { Concentration }(\mu \mathrm{g} / \mathrm{ml})\end{array}$} & \multicolumn{2}{|c|}{$\begin{array}{l}\text { Apparent Volume of } \\
\text { Distribution (1.) }\end{array}$} & \multicolumn{2}{|c|}{$\underset{(\mathrm{sec})}{\underset{\text { Elimination }}{t} \frac{1}{2}}$} \\
\hline & & & & F-11 & F-12 & F-11 & F-12 & $F-11$ & $F-12$ \\
\hline & & & & $\begin{array}{l}4.8 \\
1.6 \\
2.1 \\
2.5 \\
1.6 \\
3.7\end{array}$ & $\begin{array}{l}7 \cdot 9 \\
4 \cdot 3 \\
4 \cdot 2 \\
4 \cdot 3 \\
6 \cdot 8 \\
5 \cdot 4\end{array}$ & $\begin{array}{r}5.98 \\
17.94 \\
13.67 \\
11.48 \\
17.94 \\
7.76\end{array}$ & $\begin{array}{l}5 \cdot 19 \\
9.53 \\
9 \cdot 76 \\
9.53 \\
6.03 \\
7.59\end{array}$ & $\begin{array}{r}7 \cdot 2 \\
9 \cdot 8 \\
21 \cdot 6 \\
25 \cdot 0 \\
10 \cdot 4 \\
8 \cdot 0\end{array}$ & $\begin{array}{r}8 \cdot 1 \\
11 \cdot 2 \\
24 \cdot 7 \\
29 \cdot 7 \\
6 \cdot 0 \\
9 \cdot 0\end{array}$ \\
\hline Mean & & & 6.61 & $2 \cdot 7$ & $5 \cdot 5$ & $12 \cdot 46$ & 7.94 & $13 \cdot 7$ & $14 \cdot 8$ \\
\hline
\end{tabular}

pattern must have arisen because the inhaler was fired so late in inspiration, or after it ceased, that the fluorocarbon remained in the mouth or the upper airway dead space. Results of this type were discarded from subsequent analysis. Use of the Autohaler eliminated this concentration pattern, confirming that the device is effective in improving the timing of valve actuation in relation to inhalation.

Peak alveolar gas concentrations of F-11 and F-12 in six normal subjects are shown in Table $I$. The reproducibility of measurement in individuals where several studies were made was reasonably close. For example, four measurements were made on subject 1: the alveolar F-11 concentration on the first breath ranged from 4.1 to 5.4 $\mu \mathrm{g} / \mathrm{ml}$ (mean $4.8 \mu \mathrm{g} / \mathrm{ml}$ ).

The apparent volume of distribution of the two fluorocarbons was calculated from the amount ejected on each puff from the inhaler and the measured alveolar concentration. The mean volume of distribution of F-11 was 12.461 ., range 5.98 to 17.94 1. The corresponding values for F-12 were mean 7.941 . and range 5.19 to 9.761 . The predicted mean TLC was 6.611 , range 4.43 to $7 \cdot 771$.

There are probably two main reasons for the difference between the predicted total lung capacity and the volume of distribution of the fluorocarbons. The first is loss of fluorocarbon because the gas jet emerging from the inhaler did not all enter the mouth. The results with F-12, where the volume of distribution was $120 \%$ of total lung capacity, suggest that this was not an important source of loss. The higher distribution volumes with F-11 probably arise because of the higher boiling point and greater blood solubility of this substance than F-12 (Dollery et al., 1974). Loss by dissolving into blood in the pulmonary capillaries and into lung tissue would reduce the concentration in alveolar gas and increase the calculated volume of distribution.
The fluorocarbons were rapidly eliminated from the alveolar gas on subsequent breaths. With a breath frequency of 12-15/minute the half life of both F-11 and F-12 was 14 to 15 seconds. Two patients were studied with severe obstructive airway disease, one with a Th 1165a inhaler and the other with a Ventolin inhaler (F-11, $25 \mathrm{mg}$; F-12, $65 \mathrm{mg}$ ). The alveolar concentrations of $F-11$ were 5.0 and $3.0 \mu \mathrm{g} / \mathrm{ml}$ and the $\mathrm{F}-12$ values were 5 and $15 \mu \mathrm{g} / \mathrm{ml}$ respectively. These results are similar to those obtained in the volunteers although, as expected, the alveolar plateau was less well defined.

MULTIPLE INHALATIONS A volunteer made one inhalation from the Th 1165 a placebo on every breath for 30,60 , and 120 seconds in three separate studies (6, 12, and 24 doses respectively), while maintaining a normal level of inspiration. Alveolar gas concentrations of $\mathrm{F}-11$ and $\mathrm{F}-12$ were then monitored at a breath rate of 12 /minute; values on the first expired breath are recorded in Table II.

\section{T A B L E I I}

ALVEOLAR GAS CONCENTRATIONS OF FLUOROCARBONS11 AND -12 IN A VOLUNTEER WHO INHALED ONE PUFF FROM PLACEBO AEROSOL Th 1165a ON SUCCESSIVE BREATHS FOR 30, 60, AND 120 SECONDS $(6,12$, AND 24 DOSES RESPECTIVELY)

\begin{tabular}{|c|c|c|c|c|}
\hline $\begin{array}{c}\text { Dose } \\
\text { (no. of puffs) }\end{array}$ & \multicolumn{2}{|c|}{$\begin{array}{c}\text { Peak Alveolar Gas } \\
\text { Concentration } \\
(\mu \mathrm{g} / \mathrm{ml})\end{array}$} & \multicolumn{2}{|c|}{$\underset{(\mathrm{sec})}{\operatorname{Elimination}} \mathrm{t}_{\frac{1}{2}}$} \\
\hline \multirow[b]{2}{*}{$\begin{array}{r}6 \\
12 \\
24\end{array}$} & $F-11$ & $F-12$ & F-11 & F-12 \\
\hline & $\begin{array}{l}16 \cdot 1 \\
26 \cdot 1 \\
29 \cdot 6\end{array}$ & $\begin{array}{l}34 \cdot 2 \\
65 \cdot 0 \\
66 \cdot 9\end{array}$ & $\begin{array}{l}13 \cdot 1 \\
22 \cdot 7 \\
17 \cdot 5\end{array}$ & $\begin{array}{l}19 \cdot 1 \\
21 \cdot 4 \\
17 \cdot 9\end{array}$ \\
\hline Mean & & & $17 \cdot 8$ & $19 \cdot 5$ \\
\hline
\end{tabular}

The levels after 24 doses were only slightly higher than those after 12 and may represent the highest attainable in this mode of administration, the amount inhaled on each tidal breath being equal to the amount added from this inhaler. Expired air 
elimination was rapid and similar for the two fluorocarbons.

\section{DISCUSSION}

The observed concentrations in alveolar gas follow closely what would be predicted from injection of fluorocarbon into the inspired gas during inspiration to total lung capacity, although the F-11 concentrations in particular were lower than expected. The blood/gas partition coefficient for $\mathrm{F}-11$ is 0.9 and for $\mathrm{F}-12,0.25$, so dissolution in blood and lung tissues may account for the lower than predicted values, particularly for F-11.

The values of fluorocarbon concentration observed in alveolar gas after single discharges of the inhaler, a mean for F-11 of $2.7 \mu \mathrm{g} / \mathrm{ml}$ and for F-12 of $5.5 \mu \mathrm{g} / \mathrm{ml}$, are only $4.0 \%$ and $1.4 \%$ respectively of those which had to be maintained for five minutes in dogs to sensitize their ventricular myocardium to arrhythmias provoked by adrenaline. Furthermore, the peak concentration in alveolar gas was of very brief duration after the use of the inhaler. We have shown in other studies with labelled F-11 in rats that its distribution into and out of tissues depends upon their blood flow and the blood/ tissue partition coefficient (Williams et al., 1974). Unless there is a very great difference in the concentrations required to sensitize the human and dog hearts it appears that there could be no hazard from a single inhalation - at least in respect of the fluorocarbon propellants.

In the single study in which multiple inhalations were given, the alveolar gas concentration approached the values that sensitize the dog heart to arrhythmias, although the electrocardiogram of the volunteer was normal throughout. If the effect of different fluorocarbons is additive, as is probable because of their similar structure and mode of action, such a combined concentration might be hazardous. Thus it would be unwise for a patient to actuate the inhaler upon every breath over a period, and the instructions for use now warn against overdosage. A few normal breaths between doses would prevent accumulation of fluorocarbon in the lung.

\section{REFERENCES}

Bass, M. (1970). Sudden sniffing death. Journal of the American Medical Association, 212, 2075.

Clark, D. G. and Tinston, D. J. (1972a). Cardiac effects of isoproterenol, hypoxia, hypercapnia and fluorocarbon propellants and their use in asthma inhalers. Annals of Allergy, 30, 536.

(1972b). The influence of fluorocarbon propellants on the arrythmogenic activities of adrenaline and isoprenaline. In Toxological Problems of Drug Combinations: Proceedings on the European Society for the Study of Drug Toxicity, 13, 212. (Excerpta medica International Congress Series No. 254.)

D'Arcy, P. F. and Kirk, W. F. (1971). Development of a new device for inhalation therapy. Pharmaceutical Journal, 206, 306.

Dollery, C. T., Williams, F. M., Draffan, G. H., Wise, G., Sahyoun, H., Paterson, J. W., and Walker, S. R. (1974). Arterial blood levels of fluorocarbons in asthmatics following use of pressurised aerosols. Clinical Pharmacology and Therapeutics, in press.

Muysers, K. and Smidt, U. (1972). Clinical uses of mass spectrometry. In: Biochemical Applications of Mass Spectrometry, edited by G. R. Waller, p. 601. WileyInterscience, New York.

Speizer, F. E., Doll, R., and Heaf, P. (1968). Observations on recent increase in mortality from asthma. British Medical Journal, 1, 335.

and Strang, L. B. (1968). Investigation into use of drugs preceding death from asthma. British Medical Journal, 1, 339.

Williams, F. M., Draffan, G. H., Dollery, C. T., Clark, J. C., Palmer, A. J., and Vernon, P. (1974). Use of ${ }^{18} \mathrm{~F}$ labelled fluorocarbon-11 to investigate the fate of inhaled fluorocarbons in man and in the rat. Thorax, 29, 99. 